\title{
THE PROBLEMS FACED BY THE ENGLISH TEACHERS IN INTEGRATING THE BEHAVIOR COMPETENCE TO THE TEACHING OF ENGLISH BASED ON THE 2013 CURRICULUM AT MTsN MODEL MAKASSAR
}

\author{
Devi Ratna Sari \\ English Education Department \\ Alauddin State Islamic University of Makassar \\ ratnasaridevi25@gmail.com
}

\begin{abstract}
This study aims to describe (1) the integration of the spiritual attitude and social attitudes to the teaching of English, (2) the problems faced by English teachers in integrating spiritual attitude and social attitudes to the teaching of English, (3) the English teachers' effort to cope with the barriers in integrating spiritual attitude and social attitudes to the teaching of English in MTsN Model Makassar. The study was designed in the form of qualitative descriptive study. Subjects in this study were two English teachers in the $7^{\text {th }}$ grade of MTsN Model Makassar. The data were collected by using the methods of documenting, observation, and interviews. Data were analyzed through triangulation data. The results showed that (1) the integration of the behavior competence to the teaching of English lies on the components of planning, implementation, and assessment. The real integration is carried out by means of motivating/encouragement, warning, direction, reprimand, assignment, and reinforcement to students while participating in teaching and learning activity, (2) the obstacles faced by the English teachers (a) difficulty in reconciling the stated in lesson plan and the real activity occured in the classroom (b) difficulty in dealing with different student's character, (c) lack of time management in teaching, (d) poor management classroom, (e) the lack of infrastructure, (3) the solutions given by the english teachers sharing with Teachers Working Group (KKG), coordinating with teacher counseling and parents, good teacherstudent relationship, and provision of adequate infrastructure. Based on these findings, it can be concluded that the integration of the spiritual attitude and social attitude lies on the components of planning, implementation, and assessment of teaching. Its implementation is done by providing reinforcement to the internalization of attitudes. The obstacle lies on the planning and implementation. Advice can be given of the results of this research that teachers should more improve the accuracy in selecting the KD of KI-1 and KI-2 to be integrated into the KD of KI-3 and KI-4 in order to enact the planning conform with the implementation. For the education department, they should further enhance the delivery of training related to the implementation of the 2013 curriculum.
\end{abstract}


Sukirman, Developing English Morphology Materials For Undergraduate Students...

KEY WORDS: behavior competence, 2013 curricullum, character values integrated.

\section{A. INTRODUCTION}

$\mathbf{M}$

any studentswere entering school without the basic values that had built this country. Depressing reports of students' cheating, lack of self-discipline, brawl students, and a lackluster approach to schoolwork are common (Ryan \& Bohlin, 1999). Public schools have failed in educating Indonesian children in basic moral principles. During the last decade, this trend of neglecting to teach moral has changed with the introduction of value programs. Ryan and Bohlin states that people are now talking about the importance of behavior and personal integrity. The high level of moral degradation occurs among students and politicians (antaranews.com, 2012). The degradation of moral standards starts not only from within the home, but alsofrom the Media and eeducational system as well as eenvironmental structures play a significant role. To reach a generation that has been exposed to so much with so little maturity or understanding will not only be challenging for its teachers, but overwhelming for those that seek to control them.

The importance of behavior education is gaining momentum among politicians and educators. Over a dozen states have mandated caharacter education and hundreds of schools have incorporated it into their programming (e.g., L.A. Times, 2003). Moreover, in the last several years three top education periodicals (Educational Leadership, Phi Delta Kappan, Journal of Teacher Education) have stressed the importance of behavior, ethics, and spirituality in education. The relative neglect of moral education in the teacher curriculum has at least two proximal causes. The first is the daunting surfeit of training objectives that already crowd the academic curriculum of teaching majors. When faced with the reality of finite credit hours available for teacher education, along with the demands of accreditation and state licensing requirements, many educators assume that curriculum leaves little room for training in moral education. The second cause is the puzzling phenomena where by stakeholders, parents, and school boards expect schools to address the character of students, but nobody wants to be caught teaching values. Teachers implicitly impart values when they select and exclude topics; when they insist on correct answers; when they encourage students to seek the truth of the matter; when they establish classroom routines, form groups, enforce discipline, encourage excellence. Teachers 
mold certain forms of social life within classrooms, and influence students' experience of community and school membership. Moral values saturate the daily life of classrooms (Bryk, 1988; Goodlad, 1992; Hansen, 1993; Strike, 1996).

Behavior formation is intrinsic to school and inescapable part of the teacher's craft (Campbell, 2003; Hansen, 1993; Jackson, Boostrom \& Hansen, 1993; Lapsley \& Narvaez, 2006). The dilemma that faces educators then, is whether it is acceptable to allow behavior education to remain part of scholl hidden curriculum, or whether advocacy for the value commitments immanent to education and teaching should be transparent, intentional, and public.

Furthermore, some on-the-spot incidents also indicate the character declines of the nation. Students juvenile, free-sex among students, students' cheating during National Exam, corruptors among legislators, inter-ethnic violence, violence under the name of religions are some of the cases which eventually 'ring an alarm' that today's education has not succeeded yet to create a better moral generation, a more tolerant society, or even has not created good and honest legislators. By looking at these facts, a character education program should be revitalized. Along with those reasons in July 2013, the ministry of education Muh. Nuh published the new curriculum called the 2013 currciculum. This curriculum belives that teaching has had two primary goals: to educate people intellectually and to teach them to be morally good. In the 2013 curriculum the concept of character education inetgrates into the syllabus of teaching that is called behavior competence. From this real integration, the concept of the character education (behavior competence) is not taught seperately, but united in every subject that taught in the classroom.

In the 2013 curriculum, behavior education is integrated in every single subject. Teachers are now required to not only do a lecture, but teachers should also encourage the students to be more active, creative, and good behavior. Behavior education is embodied in the concept of the development of behavior competence based on the 2013 curriculum. It changes holisticallyand affects the teaching English. Therefore, the qualified English teacher in understanding the implementation of the curriculum plays a significance role. The teacher is one of the most important sources in the learning process to achieve the effectiveness in teaching and learning process. That is way, a teacher must be prepared to address issues then arise with the implementation of the 2013 curriculum. In the framework of the implementation of the curriculum as a whole in 2013 in Indonesia there are still many problems faced by teachers in the implementation of teaching process, especially English teachers. 
Sukirman, Developing English Morphology Materials For Undergraduate Students...

Change theteachers mindset of English in order to implement the behavior competence in the concept of integrated learning based onthe 2013 curriculum requires more insight knowledge in other words we need the development of the teacher's knowledge. It is exactly that leads to a variety of new polemic in the teaching process. Based on the previous problem above, the researcher conducted a research under the title "The Problems Faced by the English Teachers in Integrating the Behavior Competence to the Teaching of English Based on the 2013 Curriculum at MTsN Model Makassar."

\section{B. LITERATURE REVIEW}

A number of studies had been conducted in order to investigate the integration of behavior competence to the teaching and learning activity. First, Yunita, Racmat, and Erlina (2012) conducted their research the obstructions of the integration of the caharcter education on chemistry learning in all public high schools of Pontianak, found that teachers did not complete their lesson plans with all indicators of the integration of behavior values in the syllabus and lesson plans were used. While the implementation of learning chemistry by the teachers in all public school has integrated based on the attitude of the nation's cultural values through exemplary approach, conditioning and strengthening the learning activities. However, only two of public schools that integrated the cultural values and the national character in the chemistry learning. The constraints perceived by tenth grade chemistry teachers in public schools of Pontianak in integrating behavior values in chemistry teaching workload was quite large, which was considered a complicated scoring system and the lack of understanding of the integration of the behavior values.

Second, William (2002) in his research, "the effects of character education on student's behaviour in Rural school". The findings revealed that character education had a positive effect on the behavior of the students in the study based on the perceptions of the teachers, parents, and students. However, other factors may have affected students' behavior more than the character education program. It is recommended that the characer education program continue as an integral part of the curriculum of the school. All of the teachers interviewed incorporated the behavior values throughout the curriculum including art, music, and classroom disciplinary programs. The results of the study indicated improvement in the behavior of some students and it appears that the character education program may have been a primary factor in this improvement. 
In Addition, William said that the character education program appeared to be well integrated into the curriculum at this school and was the basis for classroom management and rules. Responsibility and respect were the two most prevalent changes in behavior identified by the teachers, a claim supported by the parent interviews. Another change identified was that some of the students had improved their attitude toward school or were "happier."

The researchers' findings above showed that the integration of the behavior values based on the curriculum become a primary attention to gain the intelligence students but to achieve the education goals there are many problems faced by the educators to unite it, meanwhile those research were to cope with the problems by applying some methods or techniques, no one reserachers classified their research to the specifically problems of the teachers in integrating the behavior competence to the teaching of English based on the curriculum. In this reserach, the researchers will analyzing the the problems faced by the English teachers in integrating the competence of social and religious attitude to the teaching of English based on the 2013 curriculum.

\section{Behavior}

In Undang-undang No. 20 of 2003 on the National Education System in section 3 stated that:

"National Education serves to develop the ability, the character, and the civilization of dignity in the context of the intellectual life of the nation. It is aimed for developing students' potentials to become a man of faith and devoted to God Almighty, the good behavior, healthy, knowledgeable, capable, independent, creative, responsible, and to be the democratic citizens".

Based on the statement above, it appears that the overall purpose of the national education is the development of students' behavior.

Behavior means the attitude or personality. Coon (Zubaedi, 2011: 8) defines the attitude as a subjective assessment of the person's personality associated with personality attributes that may or may not be accepted by the society. Behavior is the whole natural and dispositions that have been mastered stably which define an individual in the overall attitudes that makes the typical psychic in the way of thinking and acting.

Attitude is a psichologycal tendency that is expressed by evaluating a particular entity with some degree of favour or disfavour (Eagly and Chaiken, 1997). 
Sukirman, Developing English Morphology Materials For Undergraduate Students...

Based on the discussion above can be affirmed that the behavior is a personality that makes typical in the way of thinking and acting that is inherent in a person. Attitudes structure can be described in terms of three components.(1) Affective component: this involves a person's feelings/emotions about the attitude object. (2) Behavioral (or conative) component: the way the attitude we have influences how we act or behave. (3) Cognitive component: this involves a person's belief / knowledge about an attitude object. Good behavior consists of a process to put the good thought, to desire to do good, and to do good.

\section{Behavior Competence}

There are some notion of the behavior competence. Behavior comptence is a planned effort in implementing the education to make the students having a good character. Michigan university (2014) states behavior competencies encompass knowledge, skills, attitudes, and actions that distinguish excellent performers in order to achieve consistency of understanding. Scott (2011) argues the behavioral competence refers to the behaviors that are necessary to achieve the objective. Behavioral competency is also something you can measure and lists of competencies for describing how people perform in different situations.

This study can be affirmed that behavior competence is a planned attempts to make the students familiar with, caring, and internalize the values that students behave as a perfect man. The behavior of education is expected to amend the quality of the implementation and the outcomes of education that guides to the achievement of the formation of the character and the moral values in students as intacted, integrated and balanced.

\section{Behavior Values for Students}

Behavior values which is used as the school principal values taken/ extracted from grains of the measuremnt competency and subjects targeted to internalized by the students. The 2013 curriculum divides into two attitude competencies, as follows:

a. The behavior values in relation with Allah (religious attitude)

Thoughts, words, and actions of a person who strived always based on the values of religion.

b. The behavior values in relation with others (sicial attitude)

1) Honesty

Behavior based on an attempt to make himself as a person who always believed in words, actions, and work, both to themselves and others. 
2) Responsiblity

Attitudes and behavior of a person to carry out his/her duties and obligations as $\mathrm{h} /$ shee should do for themselves, society, the environment (natural, social and cultural), country and the Almighty God.

3) Discipline

An act which was indicating orderly behavior and obedient to the various rules and regulations.

4) Confidence

The attitude of self-confident in the ability to gain the fulfillment of every wish and hope.

5) Politeness

The refined and good attitude from the point of view of utterance and behavior pattern to everyone.

6) Caring

Caring is a level of active concern, or lack of negligence, towards avoidance of possible dangers, mistakes, pitfalls, and risks.

a) Tolerance

Tolerance is an attitude and actions to address diversity of backgrounds, views/opinions, and beliefs.

b) Mutual Cooperation

Mutual cooperation is cooperating or helping each other to achieve a common goal by sharing tasks and helping voluntarily.

\section{RESEARCH METHOD}

In this research, the researcher used a descriptive qualitative research. The descriptive study us

ed to seek a collection of instances from the data in the hope of the issue of the problems occurred. Thus, it was hoped that the integration of the behavior competence to the teaching of English based on the 2013 curriculumwould emerge.

This study was conducted at MTsN Model Makassar in the academic year 2014/2015. This study focused on describing the problems faced by the English teachers who implemented the 2013 curriculum in teaching process. There were two English teachers of the $7^{\text {th }}$ grade who become the sample here. The researcher chose this location because the 2013 curriculum was still implemented in this school.

This study were done by the researcher through 3 steps: 
Sukirman, Developing English Morphology Materials For Undergraduate Students...

\section{Documenting}

The researcher used data sources that support as follows: syllabus, annual program, semester program, methods, medium of teaching learning and lesson plan. Those data were used to foster the research finding the problems in this case. The first step was analyzing lesson plan form; adjusting the learning model of the teachers of integrated behavior competence in the English teaching process, and analyzing the core activities which was designed by the teachers; whether it could foster the integration of behavior competence or not. The second step was analyzing the syllabus by checking out the syllabus of the 2013 curriculum content. Checking the annual program and semester program of the sincronization of all activities, policies, and supportive school environment to instill the values of behavior competence of religious attitude and social attitude.

\section{Observation}

Observations was conducted by researcher using observation instruments. This observation instrument consists of a sheet of observation. It is a description of the observations teaching process in the classroom. During the observation take place, researcher uses a handy camera to record the teaching process. Observation sheet contains:

a. Observing the learning process by harmonizing the teacher's activity with the lesson plan.

b. Matching learning activities by incalculating the behavior values.

c. Adjusting the cultivated of the behavior values with the scientific approach in which teacher applies in the teaching process from opening until closing activities:

1) Opening activity: Teacher gives a greeting and praying together to inculcate religious values.

2) Core activity: teacher facilitates learners on the stages of observing, questioning, associating, experimenting, and communicating to instill a honesty, caring, respect, responsible, dare to be different, and so forth.

3) Closing activity: Teacher gives the reinforcement to foster the values of the initiative, critical thinking skills, and innovative learning.

\section{Interview}

The researcher conducted interviews with selected representatives, in this case the headmaster and the English teachers. The interview sessions conducted in a semi-structured format, approximately 15 to 35 minutes in duration, and recorded by 
the audio-taped for later transcription. A corresponding versions of this research tool were developed to guide the questions meaningfully to the resource respectively. The interview guide contains some questions about:

a. The preparation of the English teachers before teaching in the learning process of integration.

b. The selected method and media that used in the learning process of integration.

c. The ways of the English teachers implement the concept of integration both in the implementation learning phase and assessment phase.

d. The constraints faced by the English teachers in implementing the concept of integration learning.

e. The ways of the English teachers coped with the problems.

The technique of analysis data uses in this research as follow:

1) Data reduction

Data reduction is process of simplification and transformation data from the written form data through making summary, and coding.

2) Data display

The orderly information gives impossibility in order to make conclusion and take action.

3) Conclusion drawing/Verification

The meanings that is tested the validity, strength, and exactly in the really as a data validity.

\section{D.FINDING AND DISCUSSION}

This research was conducted from January till February 2015. It was conducted for five meetings for every class, started from the second weeks of January till the second weeks of February. It was found that in the planning stages the integration of spiritual attitude and social attitudes include preparing lesson plans and teaching materials. In making lesson plan, the teacher should be selecting the appropriate KD of KI-1 and KI-2 to be integrated into the KD of KI and KI-3-4 in order to make the effective teaching process. While teaching materials deserve careful consideration as an important part of the teaching process related to the achievement of the teaching goals.

1. The Integration of the Attitude Competence to the Teaching of English at MTsN Model Makassar Class VII In the Academic Year 2014/2015 
Sukirman, Developing English Morphology Materials For Undergraduate Students...

\section{a. Teaching Steps}

From the observations at the implementation stage, the steps performed in the learning process through three (3) phases, namely the beginning activity, core activity $(5 \mathrm{M})$, and the final activity. This is same with the opinion of Masnur Muslich (2007: 72) on the sub-components of the implementation of the teaching activity aimed at three aspects, in this case:

1) Opening activity

2) Core activity

3) Closing activity

These stages can stimulate the students to be active and interactive. The integration of the behavior competence is stimulated by motivating/encouragement, warning, direction, reprimand, assignment, and reinforcement to students while participating in teaching and learning activity.

Learning outcome is the result of the interaction both external and internal stimulus. Gagne (Rumiyati, 2008: 18) describes two different types of conditions that exist in learning: internal and external. Capabilities that already exist in a learner before any new learning begins make up the internal conditions necessary for learning. These internal conditions are transformed during the learning process. External conditions include different stimulus's that exist outside the learner such as the environment, the teacher, and the learning situation. This means that each new learning situation begins from a different point of prior learning and will consist of a different external situation, depending on the learner and on the learning environment. Therefore, the meaningful learning are delineated by internal and external learning conditions. The presence of the performance does not make it possible to conclude that learning has occurred; but instead, it is necessary to show that there has been a change in performance. In other words, the capability for exhibiting the performance before learning requires consideration as well as the capability that exists after learning.

From the above explanation, it can be summarized that the implementation of the teaching and learning process includes the preliminary activity, the primary activities, and the closing activity. From the scope of the teaching process should be giving the stimulus. With the stimulus interaction, the potential of the students is formed and becomes more meaningful. 


\section{b. Teaching Methods}

The Method is needed to convey the materials so that the teaching process can be implemented properly. If the method is not applied, the learning objectives will not be achieved. Rumiyati (2008: 56) describes a teaching method can be defined as the ways that can be used to implement the plan that has been prepared into the real activity to achieve the teaching objectives. There are several learning methods that can be used to implement teaching strategies include: (1) lectures, (2) demonstration, (3) discussion, (4) simulation, (5) laboratory, (6) field experience, (7) brainstorming, ( 8) debate, and so forth. Sagala (Rumiyati, 2008: 60) also said the ways of the teacher used to associate the information of facts, data, and the concept of the teaching process may occur in a strategy. In teaching, the teacher should be qualified to use or to choose the appropriate method in accordance with the material and the students' condition.

Learning methods implemented at class VII in MTs Model is the scientific approach with the strategies of teaching: debriefing, discussion, problem solving, and role plays. Scientific approach is the way of teaching which is adopting the scientific steps to build the knowledge through scientific model. The teaching model that is required may allows the cultivated of scientific thinking skills, the developed a sense of inquiry, and the developed students' ability to think creatively (Alfred De Vito, 1989). The teaching model that is needed is capable to generate the ability to learn (Joyce \& Weil: 1996), not only gained some knowledge, skills, and attitudes, but also the important is how the knowledge, skills, and attitudes acquired by the students (Zamroni, 2000 ; \& Semiawan, 1998). Those definitions are clearly explain in the regulation of Ministry education No. 65 of 2013 on Standards Process of Elementary and Secondary Education has hinted about the need for the learning process which is guided by the principles of scientific approach. Here are some explanations about the approach and the strategies:

1) Scientific Method

2) Lecture

3) Debriefing (tanya-jawab)

4) Discussion

5) Problem Solving

6) Task 
Sukirman, Developing English Morphology Materials For Undergraduate Students...

\section{c. Instructional Media}

1) Immaterial such a case, stories, legends, culture;

2) Conditional eg simulated atmosphere created before or during the process of learning takes place in the classroom;

3) Personal, such as the name or photograph or image of community leaders or heroes, drawing, the name of the president, and the king. (Udin S. Winataputra, 2009: 239)

Thus, the teaching implementation in the classroom without the use of the media will be difficult for students to understand. But with the media, the students will be active and more interactive in the teaching process so that teaching materials can be digested easily. Media for learning English is not only limited to the material, but also immaterial, conditional, and personal.

\section{d. Assessment in the Integration of Behavior competence to the Teaching of English}

Attitude competency assessment conducted in MTsN Model Makassar on stage process according to the Ministry of National Education Team (2010: 45) is a religious, honesty, discipline, responsibility, caring (tolerance and mutual cooperation), politeness, confidence in interacting effectively with the social and natural environment in the range of the association and its existence. From the description above it can be concluded that the integration of attitude competence through English subjects in the assessment phases is observation, self-correction, peer correction, and journaling.

2. The Problems in the Integration of the Behavior Competence to the Teaching of English at Class VII on MTsN Model in the Academic Year 2014/2015

In the implementation of the integration the behavior competence to the teaching of English at MTsN Model Makassar teachers are constrained many problems.

First, the difficulty of the teacher faced the time management. Allocated time is the total amount of time available for learning. Teachers who allocate more time to a specific content area have students who achieve at higher levels than teachers who allocate less time to the same content. The factors that limit learning or cause students to lose interest during the allocated timeframe, such as: 
a. Unscheduled interruptions, public announcements, and visitors.

b. Disorderly material distribution or disorganized assignment collection

c. Over-reliance on seatwork, uninteresting and overly demanding lessons and other non-engaging instructional practices. (The Florida Department of Education, 2015)

Second, having difficulty to enact the lesson plan conform with the real activity. Hamalik (2005) stated that teachers are not only required to be skilled in designing the lesson plan, but also teachers should also be able to apply them in the implementation of learning so that the design has been prepared in such a way not just lying on the table in the absence of a treatment.

Third, poor classroom management, When it comes to teaching, classroom management is a fundamental skill to master. To learn effectively, students need a positive classroom environment, free of distractions. They need to follow rules and have respect for their teacher, their peers and themselves. Just as strong classroom management can help a child to succeed, poor classroom management can interfere with the students ability to thrive and learn. In a busy classroom, some classroom noise is inevitable, whether it's from sharpening pencils, zipping and unzipping backpacks or blowing noses. However, when teachers do not control the level of noise in a classroom, the effect can be detrimental to students. For instance, a study in the Applied Cognitive Psychology journal found that background noise significantly affected a student's ability to perform complex cognitive tasks (Jenifer, 2015). If the teacher allows students to chat while teaching, playing game on handphone during silent reading or use their pencils to constantly tap, tap, tap on their desks, this behavior can set the bar low in terms of how quiet they're supposed to be during class. As a result, their ability to concentrate and, subsequently, their academic performance, can suffer.

Fourth, there is also a lack of attention to students in the teaching process. According Oemar Hamalik (2002: 16), the problem of human-related learning among others: the difficulty of the teachers to deal with the different student's character, and poor students to follow the teaching because the students are different from each other. Each student has a different character. There are students who have a good character, naughty, quiet, shy, and so forth. Based on the character of the students, teachers undergo the difficuly to cultivate spiritual and social attitudes to the students when teaching. If students who have good character and submissive, the teacher had no difficulty in instilling spiritual and social attitudes to the students. However, if the 
Sukirman, Developing English Morphology Materials For Undergraduate Students...

student has the character of quiet, shy, even naughty, teachers absolutely find the difficulty in instilling spiritual and social attitudes. Teachers have to adjust and understand the character of such students, so that the teacher can instill spiritual and social attitudes to students when learning activities. Therefore the purpose of the attitude competence can be achieved by the students.

Fifth, another problem faced is the lack of infrastructure. Oemar Hamalik (2002: 17) states the problem of teaching is on instructional and institutional. Institutional factors such confined to classrooms, laboratory practice, and so forth. While instructional issues such as lack of props. From the above explanations it can be concluded that the implementation of behavior competence through English class met the constraints. These constraints can be humane, instructional, and institutional.

3. The Solution Given in Integration the Behavior Competence to the Teaching of English at Class VII on MTsN Model Makassar in the Academic Year $2014 / 2015$

In the implementation of behavior competence teachers having some problems, but there are efforts to cope with those obstacles. First, teachers sholud be diligent to attend in teacher training. There are many teacher trainings recommended such as teacher working group; a part that can support the implementation of integration the behavior competence in MTsN Model Makassar. Mulyasa (2011: 110) states that deliberation subject teachers (MGMP) and teachers working group (KKG) are two organizations or place that can improve the professionalism and performance of teachers.

Second, Teachers also coordinating with teacher counseling and parents. Salwinsah (2009) argues "parents and schools are not wrong in educating children, therefore it must be established good cooperation between the two sides". Parents to educate their children at home, and teachers to educate children handed over to the school, to deal with the cooperation between parents and schools there should be in a same rail line in order to to be parralel in treating children, both in home and at school.

Third, the fully understand teacher (teacher disposition effective teaching); good teachers have some sort of connective capacity; they connect themselves to their students. their students to each other, and everyone to the subject being studied. In other words, teachers can be effective they must get to know each student as an individual, as a cultural being, and as a learner. So teaching is not just passing 
knowledge to students, but also can instill the spritual and social attitudes to create innovative, creative, and productive generation. According to Berliner (1988) a technique which can be applied to reduce or prevent the poor classroom management and the difficulty to deal with the different student' character: good teacher-student relationships. Some characteristics of having good teacher-student relationships in the classroom involves the appropriate levels of dominance, cooperation, and awareness of high-needs students. Dominance is defined as the teacher's ability to give clear purpose and guidance concerning student behavior and their academics. By creating and giving clear expectations and consequences for student behavior, this builds effective relationships. Such expectations may cover classroom etiquette and behavior, group work, seating arrangements, the use of equipment and materials, and also classroom disruptions. Assertive teacher behavior also reassures that thoughts and messages are being passed on to the student in an effective way. Assertive behavior can be achieved by using erect posture, appropriate tone of voice depending on the current situation, and taking care not to ignore inappropriate behavior by taking action.

Fourth, providing adequate infrastructure, a comprehensive infrastructure in school is necessary to support a learning environment. Educational facilities and educational infrastructure can be useful to support the implementation of the learning process, either directly or indirectly in an organizations in order to achieve educational goals. Infrastructure and facilities in education is one of the resources that a measure of school quality. The most important infrastructure that have to be consider in Islamic school is mosque. This infrastructure must be built with the convenience to accomodate all the society of the school. If the mosque does not accomodate all of the society of the school, the learning process may bothered. In other word inadequate infrastructure in school can make the important activity obstructed. So it should take an important attention to provide.

From the description above it can be concluded that there are some solutions that would be conducted to overcome the obstacles faced in integrating competencies through English attitudes. Solutions coordination among English teachers, counseling teachers, and parents, the fully understand teacher, following some professionalism trainings; a deliberation teachers $(K K G)$ that can be used by teachers to develop the implementation of integration the behavior competence. 
Sukirman, Developing English Morphology Materials For Undergraduate Students...

\section{E. CONCLUSION}

Based on the findings of the research and discussion in chapter IV, then proposed the following conclusion:

1. Integrating the competencies of religious attitude and social attitudes to the teaching of English conducted at MTsN Model Makassar through planning, implementation, and assessment are: (a) lesson plann is conducted by selecting the KD of KI-1 and KI-2 to be integrated into the KD of KI and KI-3-4 which are based on the syllabus and attitudes developed through lesson plans, (b) implementation study conducted by internalizing the values of attitudes in the preliminary activity, the primary activity, and the closing activity which aims to develop the student's character. In the teaching process The real integration of the behavior competence is caried out by motivating/encouragement, warning, direction, reprimand, assignment, and reinforcement to students while participating in teaching and learning activity, (c) assessment is carried out using observation, self-correction, peer correction, and journaling.

2. Barrier factors in integrating the spiritual attitude and social attitudes to the teaching of English in MTsN Model Makassar in this case: teacher is having difficulty in conforming the stated in lesson plan and the real activity occuredin the classroom, difficulty to figure out the different student's character, lack of time management in teaching, poor management classroom, and the lack of infrastructure.

3. The solution in integrating the behavior competence to the teaching of English in MTsN Model Makassar at class VII namely: enhance the fully understand teacher to deal with the different students' character so that good teacherstudents relationship achieved, participating in profesionalism teacher training; exchanging ideas in a working group of teachers (KKG), consultation with the teacher counseling and parents of the students who are misbehave, and provision adequate infrastructure.

Finally it is recommended that further researchers could focus on the obstacles of integrating behavior competence to the teaching of English based on the 2013 curriculum by taking a look to the perception between the English teachers, the students, and the supervisor of curriculum. 


\section{REFERENCES}

Abourjilie, C. Behavior Education Program. Retrieved from: www.publicschools.orgpdf. 2012.

Alfred. D. Creative Wellsprings for Science Teaching. Creative Ventures. 1989.

Alifuru. Wawancara. Retrieved from: https://www.scribd.com/doc/248524130/ WAWANCARA-docx. 2014.

Anonim. Degradasi Moral di Kalangan Pelajar. Anataranews.com. 2012.

Anonim. Undang-undang Nomor 20 Tabun 2003, tentang SistemPendidikan Nasional. Jakarta: Sinar Grafika. 2005.

Arifin, Z. Konsep dan Model Pengembangan Kurikulum. Bandung: PT. Remaja Rosdakarya. 2012.

Arikunto, S. Prosedur Penelitian Suatu Pendekatan Praktek. Rineka Cipta: Jakarta. 2013.

Azzel, M. A. Urgensi Pendidikan Karakter di Indonesia. Ar- ruz Media: Jogjakarta. 2011.

Berliner, D. C. Effective classroom management and instruction: A knowledge base for consultation. Washington DC: National Association. 1988.

Basar, A. Implementasi Pendidikan Karakter Melalui Mata Pelajaran Pendidikan Kewarganegaraan di SDN Bendungan IV Wates Kulon Progo tahun ajaran 2011/2012. Universitas Negeri Yogyakarta. 2012.

Benchmark. Mutu Pendidikan. Jakarta: Bumi Aksara. 2010.

Bryk, A. \& Schneider, B. Trust in schools. A core resource for American Jurnal. 2002.

Bryk, A. S. (1988). Musings on the moral life of schools. American Journal.

Bryk, A. S., \& Driscoll, M. The school as community: Shaping forces and consequences for students and teachers. Madison: University of Wisconsin, National Center for Effective Secondary Schools. 1988.

Campbell, E. The Ethical Teacher. Hew York: Open University Press. 2003.

Desmita. Psikologi Perkembangan Peserta Didik. Bandung: Remaja Rosdakarya. 2010.

Direktorat Jenderal Manajemen Pendidikan Dasar dan Menengah. Peraturan Menteri Pendidikan Nasional Republik Indonesia No. 41 Tabun 2007 tentang Standar Proses untuk Satuan Pendidikan Dasar dan Menengah. Jakarta.2007.

The Florida Department Education. 2015. Time on Task: A Teaching Strategy. Retrieved from:http://feaweb.org/time-on-task-a-teaching-strategythat-accelerates-learning. 
Sukirman, Developing English Morphology Materials For Undergraduate Students...

Goodlad, J. The moral dimensions of schooling and teachereducation. Journal of Moral Education, 21 (2), 87-98. 1992.

Hansen, D. T. From role to person: The moral layeredness of classroom teaching. American Educational Research Journal, 30, 651-674. 1993.

Hansen, D.T. Teaching and the moral life of classrooms. Journal fora Just \& Caring Education, 2, 59-74. 1995.

Hansen, D.T. Teaching as a moral activity. In V. Richardson (Ed.), Handbook of Research on Teaching, 4th Ed. (pp. 826-857). Washington, D.C.: AERA.2001.

Hansen, D.T. Exploring the moral heart of teaching: Towards ateacher's creed. New York: Teachers College Press. 2001.

International Journal. “Character Education”. Retrieved from: www.charactereducation. orgpdf. 2011.

Jackson, P.W., Boostrom, R.E. \& Hansen, D.T. The moral life of schools. San Francisco: Jossey-Bass. 1993.

Joyce. R.B, Weil.M. Model of Teaching. New Jersey: Brown University. 1996.

Kemendikbud. Kurikulum 2013. Retrived from: http://kemendikbud.compdf. 2013.

Kemendikbud. Pedoman Penilaian Sikap. Jakarta: Puskur. 2013.

Kosasih. D. 1985. Startegi Pengajaran Nilai Moral VCT dan Games dalam VCT. Bandung: Granesia. 1985.

Kunandar. Guru Professional. Surabaya: Kata Pena. 2013.

Kurniasih, Imas, Sani, Berlin. Implementasi Kurikulum 2013 Konsep \& Penerapan. Surabaya: Kata Pena. 2014.

Lapsley, D. K. \& Narvaez, D. Character education. In Vol. 4(A. Renninger \& I. Siegel, volume eds.), Handbook of ChildPsychology (W. Damon \& R. Lerner, Series Eds.). New York: Wile. (in press, 2006).

Lickona. T. Educating for Character. New York: Bantam. 1991.

Loeloek E P. Panduan memahamiKurikulum 2013. Jakarta: PT. Prestasi Pustakarya. 2013.

Masnur, M. Sertifikasi Guru menuju Profesionalisme Pendidik. Jakarta: Bumi Aksara. 2007.

Moleong, L. Metodologi Penelitian Kualitatif. Bandung: P'T. Rosda Karya. 2010.

Muclas, S and Hariyanto. Konsep dan Model Pendidikan Karakter. Bandung: PT Remaja Rosadakarya. 2011.

Mulyasa E. Pengembangan Implementasi Kurikulum 2013. Bandung: PT. Remaja Rosdakarya. 2013. 
Mulyasa. Manajemen Pendidikan Karakter. Jakarta: Bumi Aksara. 2011.

Narvaez, D. Integrative Ethical Education. In M. Killen \& J. Smetana (Eds.), Handbook of Moral Development (pp. 703-733). Mahwah, NJ: Erlbaum. 2006.

Narvaez. Character Education Influnces on Student Behaviour. Retrieved from: www.acdemia.edupdf. 2006.

Narwani, S. Pendidikan Karakter Pengintregasian 18 Nilai PembentukKarakter dalam Mata Pelajaran. Yogyakarta: Familia. 2011.

Nillsen, R. "The Concept of Integrity in Teaching and Learning". Retrieved from: http:/ /jutpluow.edu.au,vol, 1, 1-9Pdf. 2012.

Olsen. The Effect of Character Education on Student Behavior. Retrived from: http:// dc.etsu.edu/etd. pdf. 1995.

Richard, J. Curriculum Development in language Teaching. New York: Cambridge University Press. 2007.

Rumiyati. Pengembangan Pendidikan Karakter di SekolabDasar. Jakarta: Depdiknas. 2008.

Rusnak, P. Character Education as an Integral Part of Subject in School. Retrieved from: www.citized.info/pdf/commarticles/Character_Education_Full.doc. 1993.

Ryan. K, Bohlin. J. The Character Education Manifesto. San Fransisco: Jossey-Bass. 1999.

Ryan.K, Bohlin. J. Building Character in Schools: Practical Ways to Bring Moral Instruction to Life. San Francisco: Jossey-Bass. 1999.

Sardiman, A.M. Interaksi dan Motivasi Belajar Mengajar. Jakarta: PT. Rajagrafindo Persada. 2006.

Scott. Behavioral Competency. Retrieved from: http://youremployment.biz/competency/ behavioral-competency/2011.

Semiawan. R.C. Perkembangan \& Belajar Peserta Didik. Bandung: PT. Remaja Rosdakarya. 1998.

Strike, K. The moral responsibilities of educators. In J. Sikula, T. Buttery \& E. Grifton (Eds.), Handbook of Research On Teachereducation. (2nd Ed., pp. 869-882). New York: Macmillan. 1996.

Sugiyono. Metode Penelitian Pendidikan (Pendekatan Kuantitatif, Kualitatif, $R$ \& D). Bandung: Alfabeta. 2011.

Utami, M. Mengembangkan Bakat dan Kreativitas AnakSekolah, Petunjuk Bagi Para Guru dan Orang Tua. Jakarta: Rineka Cipta. 2009.

Wilhelm, G. A Comparative-Qualitative Research Analysis of Character Education in the Christian School and Home Education Milieu. Retrieved from: http://digitalcommons.cedarville.edu/education thesespdf. 2005. 
Sukirman, Developing English Morphology Materials For Undergraduate Students...

William. The effects of caharcter education on student's behaviour in Rural school. Retrieved from: http:// dc.etsu.edu/etd. pdf. 2002.

Yaumi, M. Pendidkan Karakter (Landasan, Pilar, dan Implementasi). Jakarta: Prenada Media Group. 2014.

Yunita, Rahmat, Erlina. Deskripsi Hambatan Pengintegrasian Pendidikan Karakter Pada Pembelajaran Kimia di SMA Negeri Se-Kota Pontianak. 2012. Not Published.

Yusuf, S. Psikologi Perkembangan Anak dan Remaja. Bandung: Rosdakarya. 2004.

Zamroni. Paradigma Pendidikan Masa Depan. Yogyakarta:Biagraf Publishing. 2000.

Zerillo, Lauren. The Face Of Character: Encouraging Morality In Children byConfronting Bullying Through Character Education. Retrieved from: joss.pages.tcnj.edu/ files/2012/04/2012-Zerillo.pdf. 2012. 